
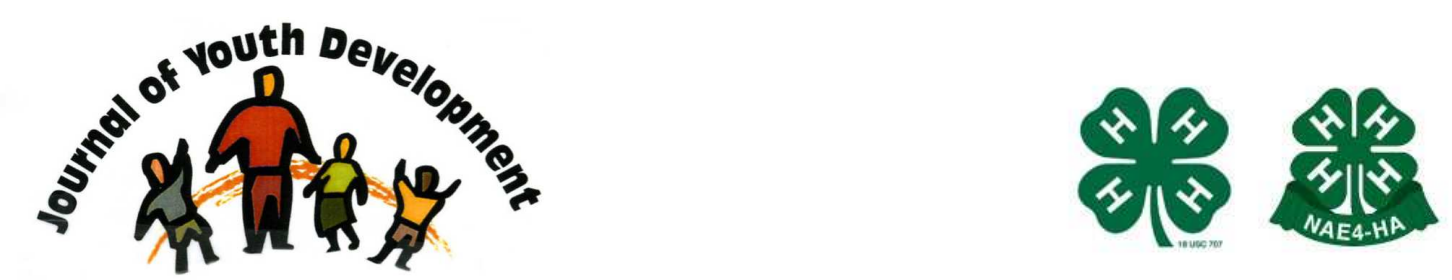

Bridging Research \& Practice

\title{
Resource Review: \\ Why So Few? Women in Science, Technology, Engineering, and Mathematics
}

Patricia A. Dawson

Oregon State University 


\title{
JOURNAL OF YOUTH DEVELOPMENT \\ bridging research and practice
}

\section{Resource Review: \\ Why So Few? Women in Science, Technology, Engineering, and Mathematics}

Patricia A. Dawson

Oregon State University

\begin{abstract}
Why So Few? Women in Science, Technology, Engineering and Mathematics" (Hill, C., Corbett, C., Rose, A., 2010) reports on an extensive study of women's underrepresentation in science, technology, engineering, and mathematics professions. Funded by the National Science Foundation, the project was conducted by American Association of University Women. The resource includes findings from eight research studies which examined social and environmental factors which contribute to women's underrepresentation in STEM fields as well as helpful tables, charts and bibliography resources. The 110 page resource will be particularly helpful for scholars working in program design to advance STEM opportunities for women.
\end{abstract}

\section{Review}

The U.S. continues to face a significant challenge as study after study notes our young people are not prepared with the necessary science, technology, engineering, and mathematics (STEM) workforce skills to compete in the $21^{\text {st }}$ Century. While the number of women in STEM fields is growing, men continue to outnumber women, especially in upper level positions. (AAUW, 2010).

"Why So Few? Women in Science, Technology, Engineering and Mathematics" (Hill, C., Corbett, C., Rose, A., 2010) reports on an extensive study of women's underrepresentation in science, technology, engineering, and mathematics professions. Funded by the National Science Foundation, the project was conducted by American Association of University Women.

The study tackles the question of why few women are becoming scientists and engineers and presents a picture of what is known as well as unknown about women in scientific professional 
fields. The study also focuses on ways communities, schools and families can create a positive environment and eliminate negative stereo types regarding women's advancement in STEM fields. Highlights from eight recent research findings provide evidence that social and environmental factors contribute to women's under representation in STEM fields are also shared by the authors.

The report is broke into nine major segments followed by extensive recommendations. Chapter topics include:

- Women and Girls in Science, Technology, Engineering and Mathematics

- Beliefs and Intelligence

- Stereotypes

- Self-Assessment

- Spatial Skills

- The College Student Experience

- University and College Faculty

- Implicit Bias

- Workplace Bias

Concluding recommendations, supporting figures and charts throughout the document as well as the extensive bibliography will prove particularly helpful for youth scholars as we consider curriculum and program designs to advance STEM opportunities.

This 110 page document is available at no charge as a download from the American Association of University Women www.aauw.org/research

\section{References}

AAUW. (2010). Why So Few? Women in Science, Technology, Engineering, and Mathematics. Hill, C., Corbett, C., \& Rose, A. Washington, DC: Author. Retrieved online at: www.aauw.org/research

(c) Copyright of Journal of Youth Development Bridging Research and Practice. Content may not be copied or emailed to multiple sites or posted to a listserv without copyright holder's express written permission. Contact Editor at: patricia.dawson@oregonstate.edu for details. However, users may print, download or email articles for individual use. ISSN 2325-4009 (Print); ISSN 2325-4017 (Online) 